\title{
Medida de la durabilidad de dos tratamientos de hidrofugación aplicados a rocas graníticas
}

\section{Durability of two water repelents applied to granite}

Fecha de recepción: 24-VII-97

T. RIVAS, B. SILVA y B. PRIETO

Fecha de aceptación: 18-XI-97

Dpto. de Edafología. Univ. de Santiago de Compostela

ESPAÑA

RESUMEN

Se presentan los resultados de la durabilidad de dos tratamientos de hidrofugación aplicados a rocas graníticas ampliamente utilizados en la construcción de edificios en Galicia (Noroeste de España). Tras la evaluación de la eficacia de dichos tratamientos, cuyos resultados se presentaron en un trabajo anterior, se someten las muestras tratadas a dos ensayos diferentes de envejecimiento acelerado: ciclos de exposición a la luz ultravioleta y ciclos de cristalización de sulfato de sodio. Los productos hidrofugantes muestran una escasa resistencia a ambos ensayos, sobre todo a los ciclos de cristalización de sulfato de sodio; esta débil durabilidad se manifiesta en una rápida pérdida de sus propiedades hidrofugantes. Asi mismo, se observa que la presencia de la capa hidrófoba en la piedra funciona como una barrera frente a la movilidad de sales, lo que ocasiona el total desprendimiento de aquella y un fuerte deterioro del material rocoso.

\section{SUMMARY}

The durability of two water-repellents for granitic stonework was determined. Weathered and sound samples of granites widely used in building construction and restoration in Galicia (NW Spain) were treated with water repellents of known efficacy, and then subjected to two artificial weathering tests: prolonged exposure to UV light, and sodium sulphate crystallization cycles. In both tests, but especially in the salt crystallization cycles, both treatments rapidly lost their water-repellency. Furthermore, the hydrophobic layer of water repellent impeded salt mobility, favouring fissuration parallel to the treated surface, which was eventually shed in the form of a plaque.

\section{INTRODUCCIÓN}

En este trabajo se presentan los resultados del estudio de la durabilidad de dos tratamientos de hidrofugación aplicados a rocas graníticas ampliamente utilizadas en el Patrimonio Monumental Construido de Galicia (Noroeste de España). En un trabajo anterior (1), se determinó la eficacia y la nocividad de estos tratamientos, encontrándose que, si bien ambos tratamientos penetran de forma muy escasa en los granitos y reducen significativamente la permeabilidad al vapor, mejoran sensiblemente su comportamiento frente al mojado superficial sin modificar el color original.

\section{INTRODUCTION}

Galicia, in NW Spain, has a rich architectural heritage, much of which is undergoing or is in need of restoration or conservation work. As part of a study of conservation treatments for granitic stonework, we have previously evaluated the efficacy and harmful effects of two polysiloxane water repellents on Galician granites (1). The results showed that although both water repellents poorly penetrated the granite surface and induced undesirably high reductions in its vapour permeability, they were nonetheless effective in improving resistance to surface wetting, and did not appreciably alter surface colour. 
Para determinar la durabilidad de los tratamientos se han sometido los granitos tratados a dos ensayos de alteración artificial en laboratorio. El primero de ellos consistió en la exposición prolongada a la radiación ultravioleta de las muestras tratadas; este test es habitualmente utilizado para valorar la durabilidad de los productos de tratamiento aplicados a materiales de construcción ya que la radiación ultravioleta constituye uno de los factores de deterioro más importantes de los polímeros orgánicos utilizados en el campo de la conservación.

El segundo ensayo realizado consistió en someter las muestras tratadas a ciclos repetitivos de cristalización de sulfato de sodio. Se eligió el sulfato de sodio para este test porque se comprobó que es una de las sales implicadas en la aparición de las formas de alteración más graves en los monumentos graníticos de Galicia, como son la desagregación arenosa y la descamación $(2,3)$. Se pretende comprobar a través de este ensayo si un tratamiento de hidrofugación sería factible en posibles actuaciones de conservación en estos edificios, teniendo en cuenta su posible contaminación por sales, especialmente sulfato de sodio, y la enorme dificultad que supone su eliminación.

\section{MATERIAL Y MÉTODOS}

Se seleccionaron tres granitos ampliamente utilizados en la construcción del Patrimonio Monumental en Galicia. El primero, denominado Roan (R), procede del Macizo del Monte Pedroso, al Oeste de Santiago de Compostela y es una de las rocas mayoritariamente utilizadas en el centro histórico de la ciudad. El granito que denominamos Baleante (B), procede de las inmediaciones de Porto do Son, en la Península del Barbanza y está siendo muy utilizado en la rehabilitación de edificios en la ciudad de Santiago por tener color y textura muy similares a Roan. El tercer granito seleccionado, denominado Axeitos (AX), procede del lugar del mismo nombre en el municipio de Riveira (A Coruña) y constituye el material de construcción de uno de los dólmenes de mayor interés arqueológico de Galicia y de la arquitectura popular de la zona. Se realizó un muestreo de los granitos seleccionados tomando muestras sanas de los tres (Roan sano-RS-; Baleante sano -BS-; Axeitos-AX) y muestras que aparentaban un estado inicial de alteración (Roan alterado-RA-; y Baleante alterado-BA-).

El estudio de estos granitos, desde el punto de vista mineralógico y petrográfico, se describe, de forma detallada, en (1). En términos generales, se observa que la diferencia esencial entre las muestras sanas y las que se han considerado alteradas reside en un mayor deterioro físico en estas últimas, que se refleja en un valor más elevado de porosidad accesible al agua. En la
In the present work, we evaluated the durability of the same two water repellents by applying them to granite blocks and then subjecting them to artificial weathering tests in the laboratory. In the first test, the treated stone was exposed to ultraviolet radiation for a prolonged period, this being a widely used method of evaluating the durability of polymer-based treatments for construction materials, which are degraded by UV light.

In the second test, treated granite blocks were subjected to salt crystallization cycles, not only to assess the effects of soluble salts on durability, but also to determine how weathering of the granite due to these salts - which are very difficult to eliminate from stonework-was affected by the presence of a water repellent. Sodium sulphate was the salt chosen because it has been implicated in the most severe forms of weathering affecting granitic buildings and monuments in Galicia: sand disaggregation, plaque-shedding and scaling $(2,3)$.

\section{MATERIAL AND METHODS}

Three granites widely used in the construction of Galicia's architectural heritage were studied: Roan granite, which is quarried near Santiago de Compostela and was extensively used in the construction of this city; Baleante granite, which is quarried from the Barbanza Peninsula (A Coruña) and is used for restoration work in Santiago because it has similar colour and texture to Roan granite; and Axeitos granite, which is quarried near Axeitos (Riveira, A Coruña) and was used in the construction of the Axeitos dolmen and of traditional structures in its vicinity. Samples of sound Roan and Baleante granites were taken (-RS- and -BS-, respectively), and also of rock that had apparently been slightly weathered (-RW-and $-\boldsymbol{B} \boldsymbol{W}$-, respectively). Only a sound sample of the Axeitos granite (-AX-) was taken.

Full details of the mineralogical and petrographic properties of these granites have been published elsewhere (1). A selection of these properties are collated in table 1. The chief difference between the sound and weathered samples of the Roan and 
tabla 1 se exponen algunos datos de interés de los granitos seleccionados.

Los productos hidrofugantes ensayados son Siliker S-101 (Wacker Química Portuguesa) y Tegosivin Ht-100 (Goldschmidt); ambos son siloxanos oligoméricos, de cadena corta, que reaccionan con el agua y se transforman en polisiloxanos. Siliker S-101 se aplica directamente mientras que Tegosivin Ht-100 se aplica diluido en White Spirit al $10 \%$, añadiendo a la dilución un catalizador en un $2 \%$ en peso de hidrofugante. La aplicación se realizó en una sola cara de las probetas de dimensiones $5 \times 5 \times 5 \mathrm{~cm}$ y $5 \times 5 \times 10 \mathrm{~cm}$, sumergiéndolas hasta una profundidad de $1 \mathrm{~cm}$ durante 30 segundos. Para determinar la durabilidad de los tratamientos, se sometieron las probetas tratadas a los siguientes ensayos de envejecimiento acelerado.
Baleante granites is that physical weathering of the latter has left them more porous to water.

The water repellents tested were Siliker $S-101$, from Wacker, and Tegosivin Ht-100, from Goldschmidt. Both are short-chain siloxane oligomers that form polysiloxanes upon reaction with water in the stonework. Siliker $S-101$ is applied directly to the stone to be treated, whereas Tegosivin Ht-100 must firstly be diluted to a 10\% (w/w) solution in White Spirit and mixed with $2 \%$ (w/w of water repellent) of a polymerization catalyst. Both were applied by immersing granitic test samples $(5$ or $10 \times 5 \times 5 \mathrm{~cm}$ cubes or rectangular blocks) in the preparation to a depth of $1 \mathrm{~cm}$ for $30 \mathrm{~s}$. After application, the block was drip-dried over the solution for $10 s$ and then its was inverted and air-dried for 30 days. Note that only one face of the test samples was treated. The durability of the water repellents was evaluated by subjecting them to artificial weathering tests, as follows.

TABLA 1 (TABLE 1)

Granulometría, porosidad accesible al agua y grado y tipo de fisuración observada mediante microscopía óptica de fluorescencia de los granitos seleccionados

(Selected properties of the granites studied as observed by optical fluorescence microscopy)

\begin{tabular}{|c|c|c|c|c|c|}
\hline Granito (Granite) & $A X$ & RS & RA (RW) & BS & BA (BW) \\
\hline $\begin{array}{c}\text { Granulometría } \\
\text { (Texture) }\end{array}$ & $\begin{array}{l}\text { Medio-gruesa } \\
\text { (Medium-coarse) }\end{array}$ & $\begin{array}{l}\text { Fina } \\
\text { (Fine) }\end{array}$ & $\begin{array}{l}\text { Fina } \\
\text { (Fine) }\end{array}$ & $\begin{array}{c}\text { Medio-gruesa } \\
\text { (Medium- } \\
\text { coarse) }\end{array}$ & $\begin{array}{l}\text { Medio-gruesa } \\
\text { (Medium- } \\
\text { coarse) }\end{array}$ \\
\hline $\begin{array}{c}\text { Porosidad } \\
\text { accesible al agua } \\
(\%) \\
\text { (Water } \\
\text { porosity (\%)) }\end{array}$ & 2,06 & 2,07 & 5,53 & 2,84 & 4,83 \\
\hline $\begin{array}{l}\text { Tipo y grado de } \\
\text { fisuración } \\
\text { predominante } \\
\text { (Dominant } \\
\text { fissuration) }\end{array}$ & $\begin{array}{c}\text { Intergranular en } \\
\text { cuarzo y } \\
\text { feldespato y } \\
\text { transgranular } \\
\text { (Intergranular } \\
\text { (quartz, feldspar) } \\
\text { and } \\
\text { transgranular) }\end{array}$ & $\begin{array}{c}\text { Intergranular en } \\
\text { cuarzo y feldespato } \\
\text { e intragranular en } \\
\text { plagioclasa } \\
\text { (Intergranular } \\
\text { (quartz, feldspar) } \\
\text { and intragranular } \\
\text { (plagioclase)) }\end{array}$ & $\begin{array}{l}\text { İdem que RS } \\
\text { pero en un } \\
\text { mayor grado } \\
\text { (As for RS } \\
\text { but more } \\
\text { severe) }\end{array}$ & $\begin{array}{l}\text { Intragranular en } \\
\text { pagioclasa, } \\
\text { inter y } \\
\text { transgranular } \\
\text { (Intragranular } \\
\text { (plagioclase) } \\
\text { and Inter- } \\
\text { and } \\
\text { transgranular) }\end{array}$ & $\begin{array}{l}\text { Ídem que en } \\
\text { BS pero en un } \\
\text { mayor grado } \\
\text { (As for BS } \\
\text { but more } \\
\text { severe) }\end{array}$ \\
\hline
\end{tabular}

\section{Ensayo de alteración artificial por exposición a luz ultravioleta}

Se utilizaron dos lámparas Phillips HPR que emiten radiación de intensidad máxima entre 300 y $400 \mathrm{~nm}$. Se sometieron al ensayo 4 probetas de dimensiones $5 \times 5 \times 5 \mathrm{~cm}$ y $5 \times 5 \times 10 \mathrm{~cm}$ de cada granito a 1.200 horas de radiación, aplicadas en ciclos de 20 horas diarias.

\section{Artificial weathering by UV light}

Four $5 \times 5 \times 5 \mathrm{~cm}$ and four $5 \times 5 \times 10 \mathrm{~cm}$ samples of each granite, two treated with Tegosivin and two treated with Siliker, were exposed to 20 h of UV radiation daily, for 50 days (1.200 h in total), from two Phillips HPR lamps emitting at maximum intensity between 300 and $400 \mathrm{~nm}$. 
Previamente al ensayo y después de períodos de 200 horas de radiación se determinan sobre las probetas las modificaciones en el color y el ángulo de contacto rocaagua, parámetro éste donde, en (1), se vio que de los métodos más comúnmente utilizados en estudios de la eficacia de tratamientos, constituye el menos dependiente del sustrato rocoso, factor que, en las rocas graníticas, posee gran importancia, debido a su marcado carácter heterogéneo.

\section{Caracterización colorimétrica}

Se utilizó un colorímetro para sólidos, expresando los datos en las coordenadas $L^{*}$,(que define la luminosidad del color) y las coordenadas $\mathrm{a}^{*} \mathrm{y} \mathrm{b}^{*}$ (que definen, respectivamente, la escala cromática del rojo al verde y del azul al amarillo) (CIE Color Space, 1976). Esta determinación se llevó a cabo en probetas de dimensiones $10 \times 5 \times 5 \mathrm{~cm}$, realizando 18-12 mediciones por probeta.

\section{Ángulo de contacto roca-agua}

El método empleado se describe en (4), consiste en dejar caer una gota de 4 microlitros desde una altura de $10 \mathrm{~mm}$ sobre la superficie de la roca y en medir, después de 10 segundos, la base (a) y la altura (h) de dicha gota mediante un micrómetro acoplado a una lupa binocular con una ampliación de 10 aumentos. Para cada superficie medida (de $25 \mathrm{~cm}^{2}$ ) se utilizaron 10 microgotas. El ángulo de contacto se determina a partir de la expresión:
Prior to the test and after every $200 \mathrm{~h}$ of exposure, the samples were examined for changes in colour and rock-water contact angle. The latter parameter was recently found to be the least dependent on the rock substrate among a selection of common measures of the efficacy of surface conservation treatments (1), which is important in the present work given granite's markedly heterogeneous character.

\section{Colorimetric characterization}

A colorimeter for solids was used to determine the colour at $10-12$ points on the treated, $10 \times 5 \mathrm{~cm}$ face of $10 \times 5 \times 5 \mathrm{~cm}$ test samples. The results are expressed as the rectangular coordinates $L^{*}$ (which defines the luminosity of the colour) and $a^{*}$ and $b^{*}$ (which define the chromatic scales from red to green and from blue to yellow, respectively).

\section{Rock-water contact angle}

The method used is fully described in reference (4), briefly, a $4 \mu \mathrm{L}$ microdroplet of distilled water was allowed to fall from a height of $10 \mathrm{~mm}$ onto the face of a $5 \times 5 \times 5 \mathrm{~cm}$ test sample. After $10 \mathrm{~s}$, the area of the base (a) and height ( $h$ ) of the drop were measured using a binocular magnifying glass equipped with a micrometer and at $10 \mathrm{X}$ magnification. Microdroplets were allowed to fall at ten different sites on the $25 \mathrm{~cm}^{2}$ treated face. In each case, the contact angle was calculated using the expression:

$$
\alpha\left(^{\circ}\right)=2 \operatorname{arctg}(2 \mathrm{~h} / \mathrm{a})
$$

\section{Ensayo de cristalización de sulfato de sodio}

Basado en (5), que consistió en 2 horas de absorción de una disolución de sulfato de sodio al $14 \%$

(estableciendo el ascenso capilar perpendicularmente a la cara tratada); 10 horas de secado a $55^{\circ} \mathrm{C}$ y $40 \% \mathrm{HR}$ y 10 horas de enfriado a $20^{\circ} \mathrm{C}$ y $80 \%$ HR. Para cada granito y producto de tratamiento se utilizaron 7 probetas. Cada 10 ciclos se lavan en agua destilada durante 7 días, se secan hasta peso constante y se determina la pérdida de peso. Cada 20 ciclos se determina el ángulo de contacto.

\section{RESULTADOS}

Antes de exponer los resultados de la durabilidad de los tratamientos, se presentan los valores del ángulo de contacto antes y después de los tratamientos así como las modificaciones producidas en el color de las rocas, ya que estos parámetros son los tomados como control en la evaluación de la durabilidad de los productos hidrofugantes.

\section{Sodium sulphate crystallization tests}

Based on that described in reference (5), was stood with its treated face uppermost in a $14 \%(w / w)$ solution of sodium sulphate for $2 h$ (during which time the salt solution entered the granite by capillary action); for $10 \mathrm{~h}$ at $55^{\circ} \mathrm{C}$ and $40 \% \mathrm{RH}$, and then for $10 \mathrm{~h}$ at $20^{\circ} \mathrm{C}$ and $80 \%$ RH. Every 10 cycles test samples were removed, washed by immersing them in distilled water for 7 days, until their mass was constant, and the mass loss was determined. Every 20 cycles the rock-water contact angle of a washed and dried samples was determined.

\section{RESULTS}

Before explaining the results of the durability of the treatments, the following is a brief explanation of the data relating to the angle of contact before and after treatments and the modifications in the colour of the rocks. These data are used as a reference in order to evaluate the durability of the water-repellents. 
La eficacia de los productos hidrofugantes se manifiesta en un incremento significativo de los valores del ángulo de contacto roca-agua (Tabla 2); antes de los tratamientos los valores de este parámetro no superan en ningún granito los $90^{\circ}$ (valor que caracteriza a las rocas como superficies hidrófilas) mientras que tras los tratamientos, los valores aumentan por encima de $100^{\circ}$, independientemente del sustrato rocoso, sean granitos sanos o alterados. En todos los casos, el producto Siliker presenta una mayor eficacia en la hidrofugación que Tegosivin.

A simple vista no se aprecia modificación en el color de las rocas después de los tratamientos, pero el colorímetro utilizado es suficientemente sensible como para detectar pequeños cambios en las tres coordenadas que se producen, especialmente con Siliker: Los valores de la coordenada $L^{*}$ sufren una disminución, lo que implica un ligero oscurecimiento de la superficie rocosa, y los valores de las coordenadas $\mathrm{a}^{*} \mathrm{y} \mathrm{b}^{*}$ aumentan, es decir, los tratamientos tienden a aumentar la tonalidad amarilla de las rocas.

Esas modificaciones se producen con un consumo y profundidad de penetración muy bajos (1). Por otra parte, se observan diferencias entre ambos tratamientos en cuanto a la cantidad de materia seca activa que permanece tras la polimeración, encontrándose más cantidad de Tegosivin que de Siliker (1), hecho que, ante los resultados obtenidos, no parece determinar una mayor eficacia.

\section{DURABILIDAD DE LOS TRATAMIENTOS}

\section{Ciclos de exposición a la luz ultravioleta}

Variaciones en el color

Tras 1.200 horas de exposición a la luz ultravioleta, se aprecian ligeras variaciones en los valores de las coordenadas colorimétricas. En la figura 1 se presentan
The rock-water contact angles before and after treatment of the granites are listed (Table 2). The water-repelling action of the treatments was manifest as an increase in the rockwater contact angle, which was $<90^{\circ}$ for all the untreated granite samples, indicating their surfaces to be hydrophilic. The largest increases occurred for the samples treated with the Siliker water repellent. The degree of alteration of the granite substrate had no clear effect on the size of the increase produced.

The naked eye detected no alteration of surface colour following application of either of the water repellents. Nonetheless, small changes in the colour coordinates $L^{*}, a^{*}$ and $b^{*}$ were detected using the colorimeter. The magnitude of these changes was generally greater for the Siliker product. The values of $L^{*}$ decreased, except in the case of the $\boldsymbol{B} W$ granite treated with Tegosivin, indicating darkening of the surface colour. By contrast, the chromaticity coordinates $a^{*}$ and $b^{*}$ increased after treatment, indicating enhancement of the yellow hue of the stone surface.

The above changes have occurred with low uptake and shallow penetration of water repellent into the granite (1). Moreover, the amount of water repellent remaining at the stone surface after polymerization has been shown to be greater for Tegosivin than for Siliker (1). Given the larger increases in rock-water contact angle induced by Siliker, uptake of water repellent would appear not to determine the efficacy of the treatment.

\section{DURABILITY OF THE TREATMENTS}

\section{Effects of exposure to UV light}

\section{Effects on surface colour.}

Figure 1 summarizes the changes occurring in the colour coordinates $L^{*}, a^{*}$ and $b^{*}$ during 1,200 hours ' irradiation of treated granite samples. For the AX

TABLA 2 (TABLE 2)

Valores medios del ángulo de contacto roca-agua $\left({ }^{\circ}\right)$, antes y después de los tratamientos (Mean rock-water contact angles for the untreated and treated granites)

\begin{tabular}{|c|c|c|c||}
\hline & SIN TRATAR (UNTREA TED) & TEGOSIVIN & SILIKER \\
\hline AX & 50 & 108 & 133 \\
RS & 62 & 109 & 131 \\
RA (RW) & 64 & 107 & 126 \\
BS & 58 & 103 & 135 \\
BA (BW) & 59 & 110 & 134 \\
\hline
\end{tabular}



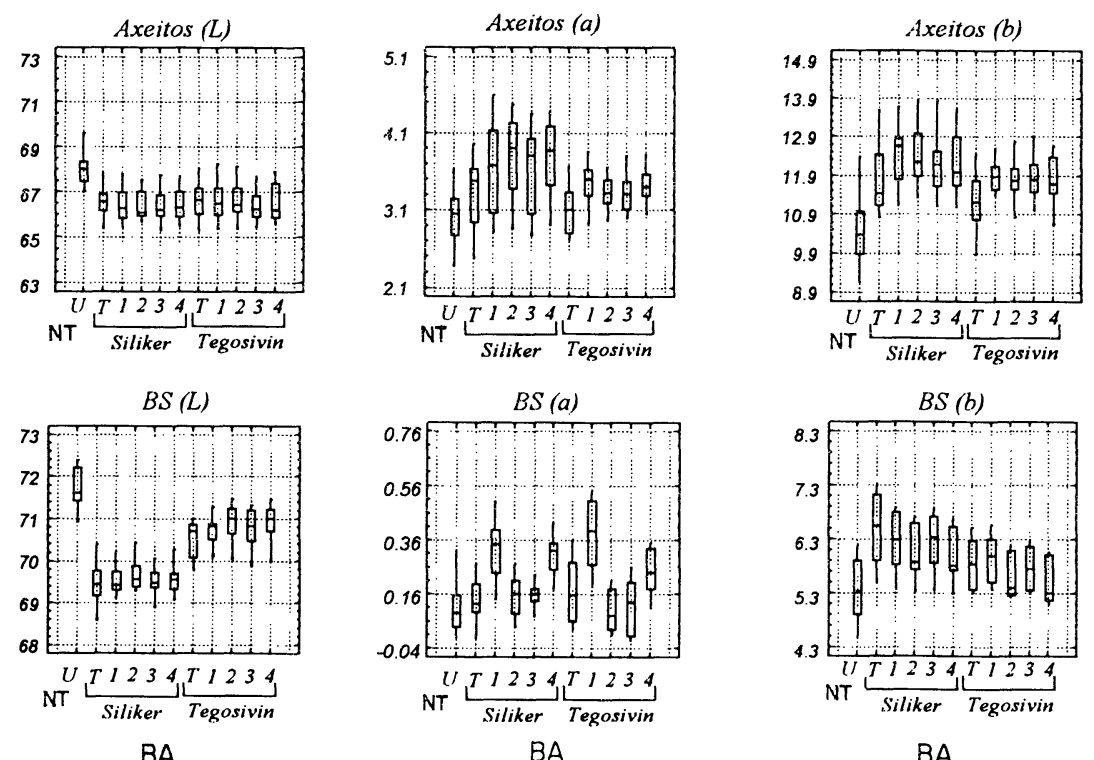

BA
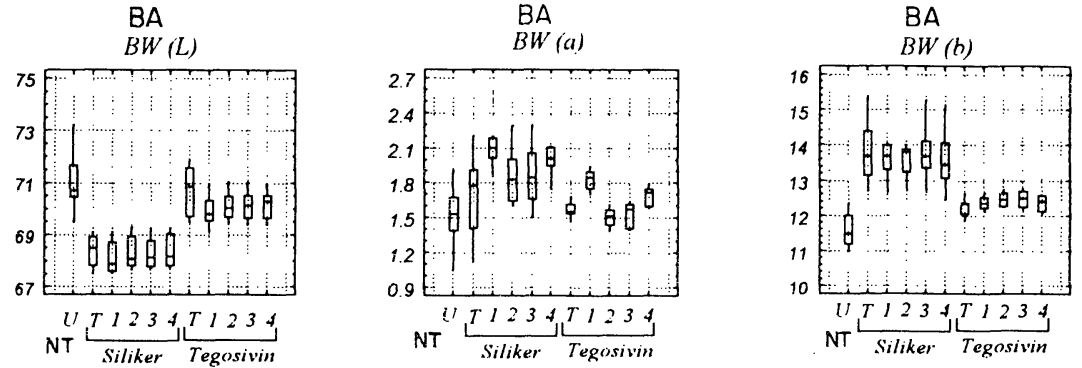

Fig. 1.- Distribuciones de los valores de las coordenadas $L^{*}, a^{*}$ y b* en AX, BS y BA a lo largo del ensayo de exposición a la luz ultravioleta. NT: granito no tratado; T: granito tratado con uno de los tratamientos antes del comienzo el ensayo. 1:200 horas de exposición; $2: 400$ horas; $3: 800$ horas; $4: 1.200$ horas.

Fig. 1.- Box-and-whisker plots showing the changes in the distributions of the colour coordinates $L^{*}, a^{*}$ and $b^{*}$ upon UV irradiation of the AX, BS and BW granites. U: untreated; T: treated. 1: 200 hours' irradiation; 2: 400 hours; 3: 800 hours; $4: 1.200$ hours.

las distribuciones de los valores de las tres coordenadas antes de los tratamientos, después de la aplicación de cada producto y tras $200,400,800$ y 1.200 horas de exposición a la luz ultravioleta. La coordenada $\mathrm{L}^{*}$ en AX no varía a lo largo del ensayo en ningún caso pero sí lo hace en BA y BS tratados con Tegosivin tras 200 horas de exposición. En el primer granito, los valores de esta coordenada disminuyen, lo cual indica que la superficie rocosa se oscurece todavía más, y en el segundo sufren un ligero aumento que indica que la luminosidad de la superficie tratada tiende a su estado original antes del tratamiento.

La coordenada $\mathrm{a}^{*}$ sufre un aumento desde las primeras 200 horas de exposición en $\mathbf{A X}$ tratado con ambos hidrofugantes y en BA tratado con Siliker. En este mismo granito tratado con Tegosivin y en BS tratado con ambos productos se observa un ligero aumento del valor de esta coordenada tras las primeras 200 horas, una disminución de su valor tras 400 y 800 horas y de nuevo un aumento tras 1.200 horas.

La coordenada $b^{*}$ experimenta un ligero aumento a partir de 200 horas en $\mathrm{AX}$ tratado con ambos productos granite and the $\boldsymbol{B S}$ and $\boldsymbol{B} \boldsymbol{W}$ granites treated with Siliker, the lightness $\left(L^{*}\right)$ of the surface colour did not vary appreciably during this period. By contrast, for the BS granite treated with Tegosivin, $L^{*}$ slightly increased, indicating that the stone surface had begun to regain its original, lighter colour; and for the $\boldsymbol{B W}$ granite treated with Tegosivin, $L^{*}$ slightly decreased, indicating further darkening of the surface colour.

The chromaticity coordinate $a^{*}$ increased for the $A X$ granite regardless of the water-repellent treatment, and also for the $\boldsymbol{B W}$ granite treated with Siliker. For the $\boldsymbol{B W}$ granite treated with Tegosivin and the BS granite treated with either water repellent, $a^{*}$ followed $a$ complex pattern, generally increasing after $200 \mathrm{~h}$, then declining until $1.200 \mathrm{~h}$ and increasing again thereafter.

After 200 hours ' irradiation, the chromaticity coordinate $b^{*}$ had increased for both treated $A X$ 
y en BA tratado con Tegosivin. En BS, tratado con ambos productos, disminuye.

Estas variaciones, aunque son tan ligeras que son dificilmente apreciables a simple vista, indican que los productos hidrofugantes están sufriendo un deterioro con la exposición a la luz ultravioleta, sin observarse una mayor resistencia en alguno de los dos tratamientos. Este deterioro llevaría a que el color de las muestras tendiera al valor original de las rocas sin tratar; es decir, que la coordenada $\mathrm{L}^{*}$ aumentara (pues disminuyó con el tratamiento) y las coordenadas $\mathrm{a}^{*} \mathrm{y} \mathrm{b}^{*}$ disminuyeran (pues aumentaron con la aplicación de los productos). Sin embargo, esto no ocurre así, indicando que el deterioro de los productos da lugar a un residuo que con el tiempo puede dar lugar a cambios apreciables en el color de las rocas.

\section{Ángulo de contacto roca-agua}

Con respecto a los valores del ángulo de contacto rocaagua (Figura 2) se observa que la resistencia de ambos productos frente a este ensayo es diferente: el tratamiento que conserva por más tiempo sus propiedades hidrófugas es Siliker, el cual mantiene todavía valores del ángulo de contacto por encima de $90^{\circ}$ hasta las 1.200 horas de exposición en todos los granitos excepto en BS. Tegosivin, por el contrario, pierde sus propiedades tras 400 horas de exposición en AX y tras 800 horas en BS y BA. granite samples. It had also increased slightly for the Tegosivin treated $B W$ granite samples. For the $B S$ granite, $b^{*}$ for both the Siliker-and the Tegosivin-treated samples decreased.

The overall variations in colour were so slight as to be barely appreciable with the naked eye. Nonetheless, the small variations in $L^{*}, a^{*}$ and $b^{*}$ suggest that both Tegosivin and Siliker degrade upon exposure to $U V$ light, neither offering better resistance to this degradation than the other. The fact that the pattern of changes is not simply the reverse of the changes following treatment (i.e. not simply increases in $L^{*}$ and decreases in $a^{*}$ and $b^{*}$ ) suggests that coloured degradation products are form that could, over time, cause appreciable changes in the colour of stonework.

\section{Effects on rock-water contact angle}

Figure 2 summarizes the changes occurring in the rockwater contact angle during UV irradiation of the $A X$, $\boldsymbol{B S}$ and $\boldsymbol{B} \boldsymbol{W}$ granites. The Siliker treatment conserved its water-repellent properties longest, as was evidenced by the observation that the rock-water contact angles for all but the BS granite samples treated with this product were greater than $90^{\circ}$ even after up to $1.200 \mathrm{~h}$ of UV irradiation. By contrast, Tegosivin lost its waterrepellency after only $400 \mathrm{~h}$ for the $A X$ granite, and after only $800 \mathrm{~h}$ for the $\mathrm{BS}$ and $\boldsymbol{B W}$ granites.

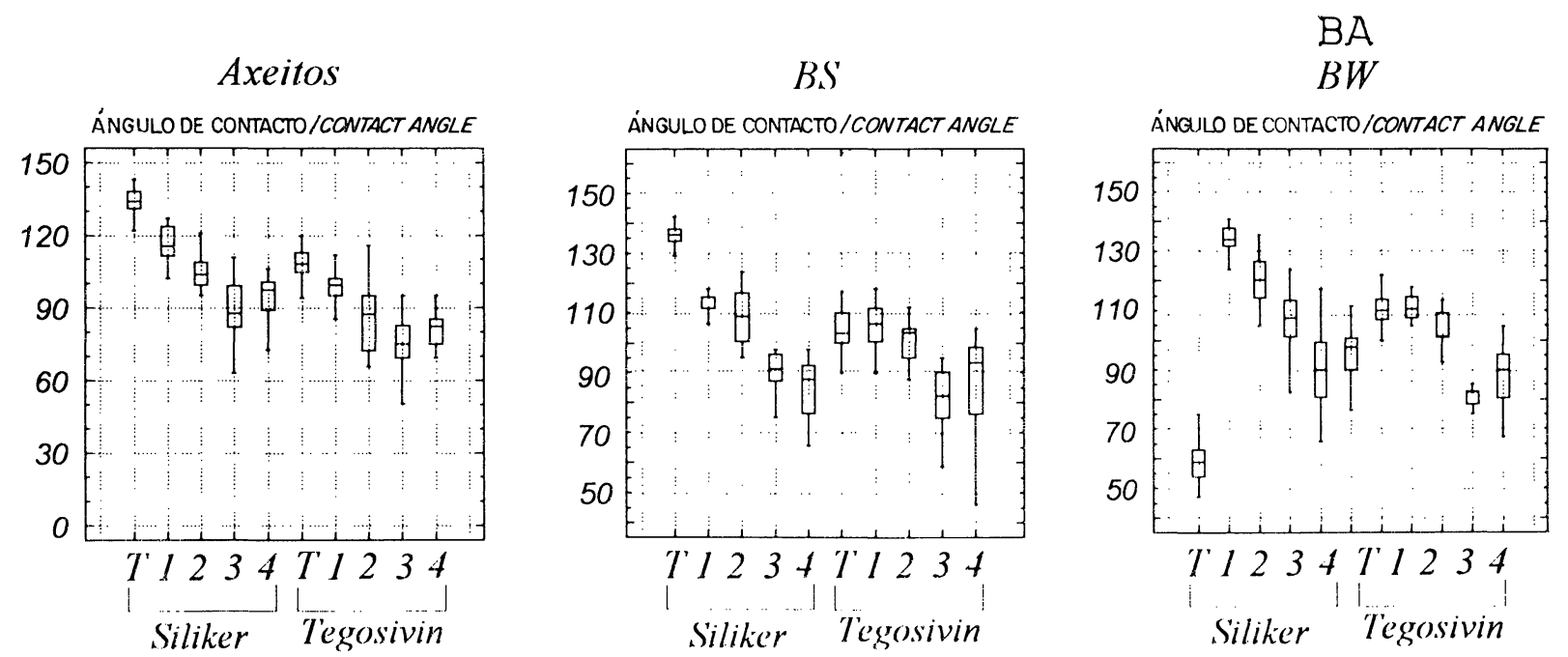

Fig. 2.- Distribuciones de los valores del ángulo de contacto roca-agua de los granitos AX, BS y BA a lo largo del ensayo de exposición a la luz ultravioleta. Tratados antes de comenzar el ensayo (T), tras 200 horas de exposición (1), 400 horas (2), 800 horas (3) y 1.200 horas (4).

Fig. 2.- Box-and-whisker plots showing the changes in the distributions of the rock-water contact angle upon UV irradiation of the AX, BS and BW granites. (T) treated, (1) 200 hours' irradiation, (2) 400 hours, (3) 800 hours and (4) 1.200 hours. 
La pérdida de la eficacia en la hidrofugación de ambos tratamientos frente a este ensayo corrobora lo obtenido con la medidas colorimétricas y señalan que efectivamente, los productos hirofugantes se alteran con la luz ultravioleta.

\section{Ensayo de cristalización de sulfato de sodio}

A lo largo de este ensayo, el poder hidrofugante de los dos productos, determinado mediante el ángulo de contacto roca-agua, sufre una importante disminución (Figura 3): a los 20 ciclos, todas las muestras tratadas con Tegosivin, excepto RA y BA, pierden su carácter hidrofugante, es decir, los valores del ángulo de contacto descienden por debajo de $90^{\circ}$; tras el mismo número de ciclos, Siliker mantiene sus propiedades hidrófugas en todos los granitos excepto en BA. A partir de 40 ciclos, ninguna muestra posee ya características hidrófobas.

Al mismo tiempo que la capacidad hidrofugante se pierde, los materiales rocosos sufren un importante deterioro físico, en forma de desagregación arenosa y de desplacación, cuya intensidad fue independiente del producto aplicado. Las muestras graníticas más porosas (BA y RA) comenzaron a sufrir a partir de los primeros 20 ciclos desagregación arenosa en las bases de las probetas en contacto con la disolución y en las caras laterales de las mismas hasta la altura del área hidrofugada. 10 ciclos después, esta misma forma de deterioro comenzó a manifestarse en los granitos menos porosos.

Por otra parte, también a partir de los primeros 10 ciclos, todos las muestras graníticas, excepto $\mathbf{A X}$, manifestaron la formación de fisuras paralelamente a la cara tratada con los productos.

A partir de los 20 ciclos, en los granitos más porosos (RA y BA) se produjo el total desprendimiento de la cara tratada, en forma de una placa de un grosor mínimo de $5 \mathrm{~mm}$. Los granitos RS y BS sufrieron esta desplacación a partir de los 30 ciclos (Foto 1).

La pérdida de peso durante el ensayo fue notoria en los granitos más porosos $\mathrm{y}$, si bien se atribuye a la desagregación arenosa sufrida por las probetas, se obseva que esta pérdida fue más intensa en las muestras tratadas con Tegosivin (Figura 4).

\section{CONCLUSIONES}

Los productos hidrofugantes, que confieren una buena hidrorrepelencia a las rocas graníticas (1), muestran, sin embargo, una débil durabilidad frente a la luz ultravioleta. Durante el ensayo, el color de las muestras tratadas se vio modificado, si bien muy ligeramente, y
These results are in keeping with the effects observed on the colour of the granites, and likewise suggest that the water repellents degrade under UV irradiation.

\section{Sodium sulphate crystallization tests}

Effects on rock-water contact angle. Both Siliker and Tegosivin lost their water-repellent action in the course of the sodium sulphate crystallization tests (Figure 3). After only 20 cycles, all the samples treated with Tegosivin, except the $\boldsymbol{R} \boldsymbol{W}$ and $\boldsymbol{B} \boldsymbol{W}$ granites, had rockwater contact angles $<90^{\circ}$. By contrast, after the same number of cycles, all the granites but the $\boldsymbol{B} \boldsymbol{W}$ granite samples treated with Siliker retained their waterrepellency. After 40 cycles, none of the samples showed rock-water contact angles consistent with hydrophobicity.

In the course of the tests, concurrent with the loss of water-repellency, all the samples underwent physical deterioration in the form of sand disaggregation and plaque-shedding. The intensity of this deterioration was apparently independent of the water repellent applied. After 20 cycles, the most porous granites, BW and $\boldsymbol{R} W$, showed sand disaggregation on the faces in contact with the sodium sulphate solution and on the sides of the test sample, up to the height corresponding to the area treated by the water repellent $(\mathrm{ca}$. $1 \mathrm{~cm}$ from the top). After 30 cycles, this deterioration was also evident on the rest of the samples.

After 10 cycles, fissuration parallel to the treated face occurred for all the samples except the AX granite.

After 20 cycles, the treated faces of the most porous granites ( $\boldsymbol{R} \boldsymbol{W}$ and $\boldsymbol{B} \boldsymbol{W})$ was shed in the form of a plaque of thickness $5 \mathrm{~mm}$. After 30 cycles, the treated faces of the $\boldsymbol{R S}$ and $\boldsymbol{B S}$ granites were likewise shed (Photo 1).

During the sodium sulphate crystallization tests, the most porous granites showed a marked mass loss attributable to sand disaggregation from the untreated faces of the test samples, interestingly, these mass losses were greatest for the samples treated with Tegosivin (Figure 4).

\section{CONCLUSIONS}

Both the water repellents tested have previously been shown to be effective when applied to granite (1). In the present work, both were found to be degraded by ultraviolet light, which led to a decrease in their waterrepellency (rock-water contact angle diminished) and to 
Tegosivin

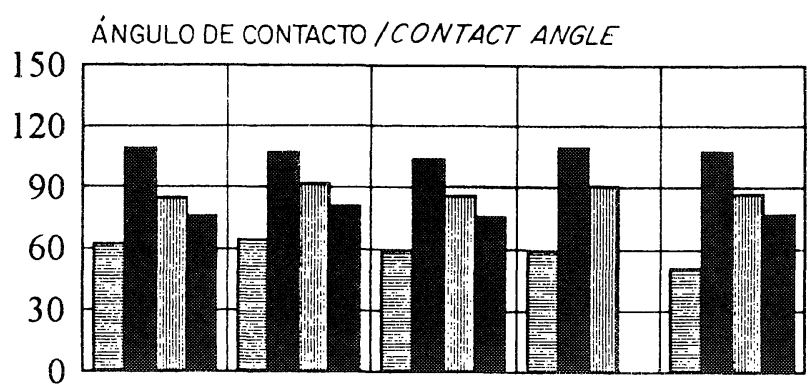

Siliker

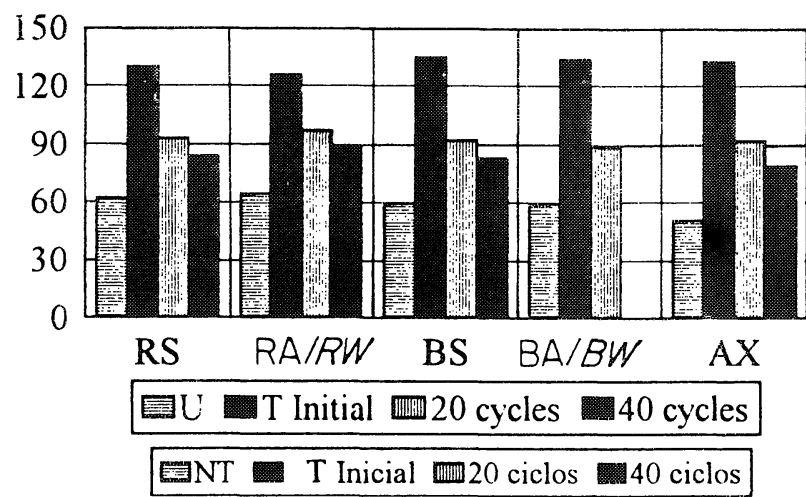

Fig. 3.- Variación de los valores del ángulo de contacto roca-agua de las cinco muestras graníticas tras 20 y 40 ciclos del ensayo de cristalización de sulfato sódico. NT: granito no tratado; T inicial: granito tratado antes de comenzar el ensayo.

Fig. 3.- Variation in the rock-water contact angle of the granites during the sodium sulphate crystallization tests. U: untreated; Tinitial: treated granite prior to testing.
Tegosivin

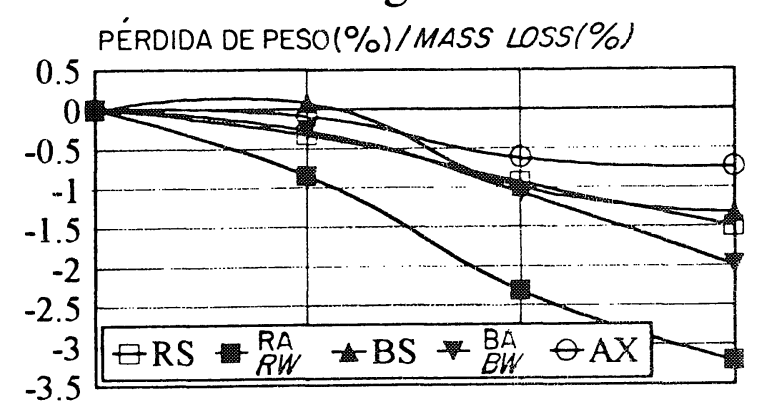

\section{Siliker}

PÉRDIDA DE PESO (\%) / MASS LOSS $1 \%$ )

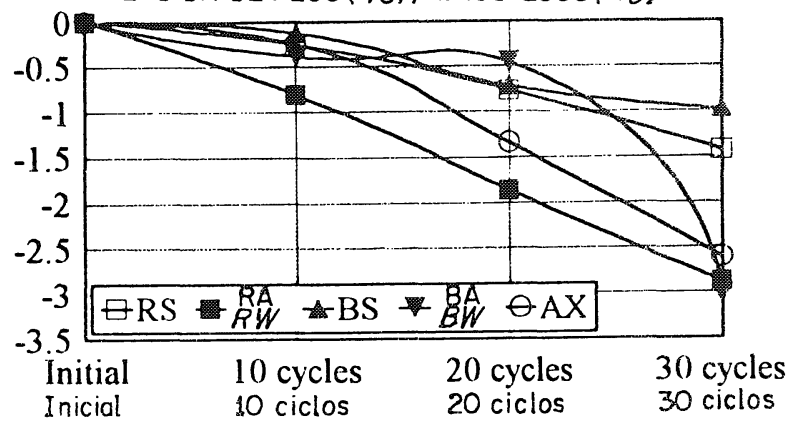

Fig. 4.- Pérdida de peso de las cinco muestras tratadas tras 10,20 y 30 ciclos del ensayo de cristalización de sulfato de sodio.

Fig. 4.- Mass losses of the five granites during the sodium sulphate crystallization tests.

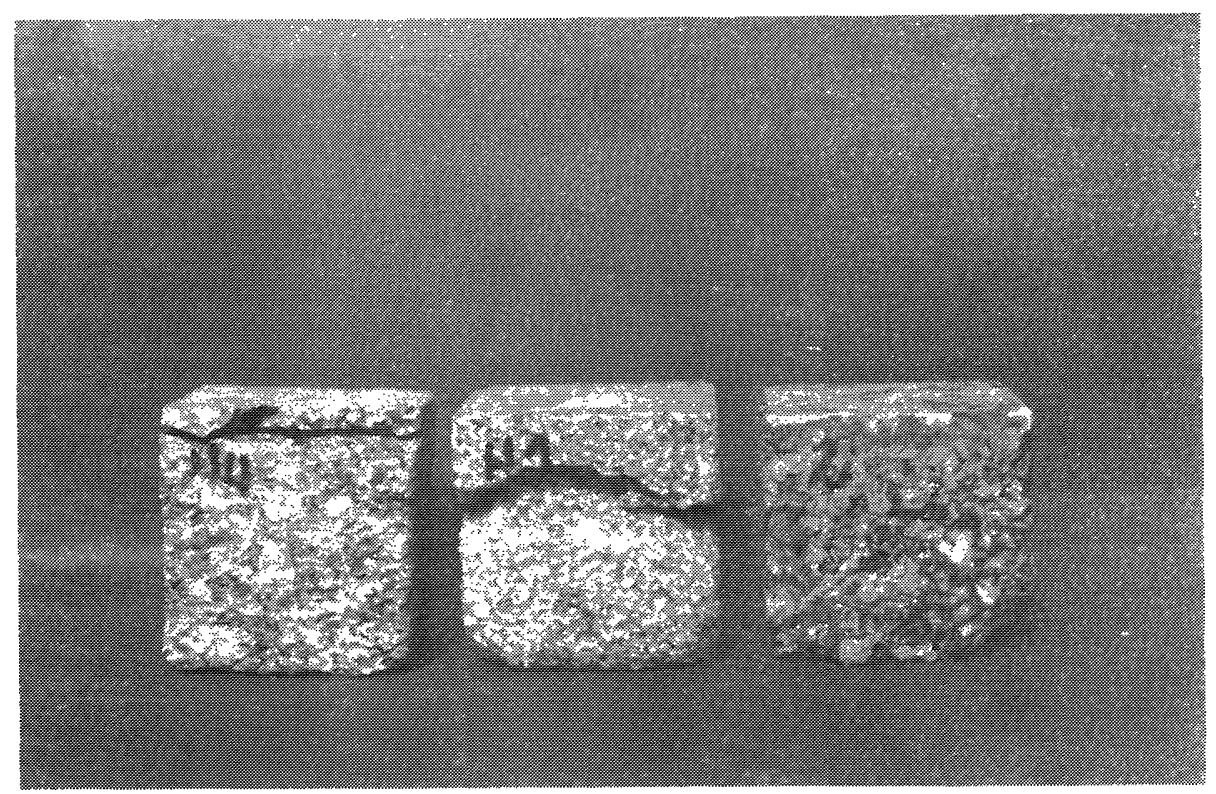

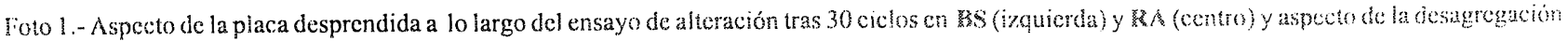
arcnosa en una probeta de $\mathrm{AX}$ tras el mismo número déciclos (derecha)

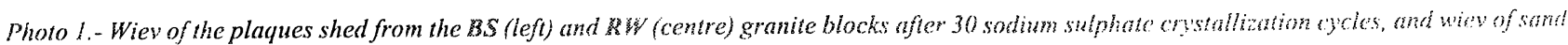
disaggregation on an AX test sample after $30 \mathrm{cycles}$ (right; treated face uppermost). 
no precisamente en el sentido de recuperar el color original, sino incrementando su oscurecimiento, lo que revela que los productos deteriorados dejan un residuo que bien pudiera causar mayores cambios de color a más largo plazo. Por otra parte, la radiación ultravioleta hace perder bastante rápidamente el carácter hidrófobo adquirido con los tratamientos, tal como indica la disminución del ángulo de contacto roca-agua. Se encuentra también que la cantidad de materia activa que permanece en la muestra rocosa tras la polimeración no parece ser el factor determinante de una mayor durabilidad, pues el producto Siliker, el cual se encontró en menor cantidad, es, de los dos hidrofugantes, el que manifiesta una mayor durabilidad a los ensayos.

El efecto de la cristalización de sulfato de sodio sobre las muestras tratadas resultó muy negativo, pues el carácter hidrófobo se pierde rápidamente durante este ensayo. Por otra parte, este ensayo tiene un efecto muy deteriorante sobre los materiales rocosos debido, precisamente a la presencia de los tratamientos en la piedra: la existencia de la barrera hidrófoba provoca la rápida formación de fisuras que ocasionan la separación completa de la capa hidrofugada. Esto implica que estos productos y en general cualquier producto hidrofugante, debe aplicarse con extrema precaución en paramentos que sean susceptibles al efecto de las sales solubles, incluso cuando éstas estén presentes en la piedra en una baja concentración.

\section{AGRADECIMIENTOS}

Este trabajo está financiado por la DGCICYT a través del Proyecto de Investigación SEC94-0381. Gracias a José María Calvo y a Elvio Ramos por su ayuda en el trabajo experimental. measurable, though imperceptible, darkening of the colour of the treated stone. This suggests that the water repellent degrades to a poorly hydrophobic residue that could have marked effects on the colour of the treated stone in the long term. Siliker $\mathbf{S}-101$ retained its waterrepellency longer than Tegosivin $\mathrm{Ht}-100$, even though more Tegosivin than Siliker remained at the stone surface after polymerization.
The treated granite test samples were severely affected by the sodium sulphate crystallization tests. The rockwater contact angle decreased rapidly, indicating a loss of hydrophobicity. Also, the hydrophobic barrier resulting from application of the water repellent favoured fissuration parallel to the treated face and, ultimately, the shedding of surface rock from that face. In view of this result, water repellents, and indeed any hydrophobic treatment, should be applied with extreme care to stonework subject to accumulation of soluble salts, or to stonework in which such salts are present at low concentrations.

\section{ACKNOWLEDGEMENTS}

This work was funded by the Spanish DGCICYT as part of Research Project SEC94-0381. The authors thank José Maria Calvo and Elvio Ramos for their help with the experimental work.

\section{BIBLIOGRAFÍA}

(1) RIVAS, T.; PRIETO, T.; SILVA, B., (1997).- Medida de la eficacia de dos hidrofugantes aplicados a rocas graníticas. Materiales de Construcción, $\mathrm{n}^{\circ} 249$.

(2) RIVAS, T., (1997).- Mecanismos de alteración de rocas graníticas usadas en la construcción de edificios antiguos de Galicia. Servicio de Publicaciones de la Universidad de Santiago. 366 pp.

(3) SILVA, B.; RIVAS, T.; PRIETO, B., Relation between type of soluble salts and decay forms in granitic coastal churches in Galicia (NW Spain). Proceedings of E.C. Research Workshop Origin, Mechanisms and Effects of Salts on Degradation of Monuments in Marine and Continental Environments. Bary (Italy), marzo, 1996.

(4) FERREIRA, A.P., (1993).- Conservaçao de pedras graníticas. Estudo da acçao de hidrófugos. Dissertaçao para a obtençao do grau de mestre en construç̧ao. Itto. Superior Técnico, Universidade Tecnica de Lisboa. $185 \mathrm{pp}$.

(5) Reunion Internationale des Laboratoires d'Essais et de Recherche sur les Materiaux et les Constructions (R.I.L.E.M.). (1978).Crystallization Test by Partial Inmersion (Test V.2.) Proc. Int. Symp. Deterioration and Conservation of Stone Monuments (UNESCO-RILEM), Paris, 1978. 